Katarzyna Mikotajczyk

\title{
Zmienność struktury wydatków publicznych: analiza porównawcza dla krajów Europy środkowo-wschodniej
}

\section{VARIABILITY OF PUBLIC EXPENDITURE STRUCTURES: COMPARATIVE ANALYSIS FOR CENTRAL AND EAST EUROPEAN COUNTRIES}

\begin{abstract}
W artykule przedstawiono analizę porównawcza zmienności struktury wydatków publicznych w krajach Europy Środkowo-Wschodniej w okresie 1995-2017. W tym celu zbudowano dwa wskaźniki zmienności, jeden odzwierciedlajacy zmienność struktury wydatków, drugi zaś zmienność poszczególnych kategorii wydatków. Powyższe wskaźniki pozwolity na weryfikację hipotezy badawczej, że najsilniejsze zmiany struktury wydatków następuja w okresach osłabienia gospodarczego $i$ dotyczq szczególnie kategorii wydatkowych majacych bezpośredni wptyw na gospodarkę. W krajach Europy Środkowo-Wschodniej największa zmienność struktury wydatków wykazały kraje o najniższym poziomie wydatków publicznych $w$ relacji do PKB, co potwierdza, że maty budżet wymusza jego racjonalizację. Z kolei największa stabilnościq struktury wydatków w badanym okresie wyróżniła się Polska, co można wiazać z najbardziej wyrównanym wzrostem i uniknięciem recesji gospodarczej. Grupq wydatków, która była najbardziej aktywnie kształtowana, zarówno w starych jak i nowych krajach członkowskich UE, byty wydatki na sprawy gospodarcze.'
\end{abstract}

Slowa kluczowe: wydatki publiczne, klasyfikacja COFOG, struktura wydatków publicznych, Europa Środkowo-Wschodnia.

JEL Codes: H50, O23.

\section{Wstęp}

Jednym z podstawowych elementów polityki finansowej państwa jest kształtowanie wysokości i struktury wydatków publicznych, są one bowiem ważnym instrumentem realizacji zadań politycznych i ekonomiczno-społecznych. Wysokość wydatków publicznych z jednej strony uzależniona jest od bieżącej sytuacji ekonomicznej, z drugiej zaś może być wykorzystywana, poprzez efekt mnożnikowy, do aktywnego kształtowania wzrostu gospodarczego i zmniejszania nierówności społecznych. Zwiększenie wydatków publicznych wymaga jednak zwiększenia dochodów publicznych lub finansowania ich z deficytu budżetowego, co w sytuacji ograniczonego wzrostu gospodarczego oraz silnej presji na ograniczenie nierównowagi budżetowej, staje się niemożliwe. Możliwym rozwiązaniem pozostaje zatem optymalizacja struktury wydatków budżetowych, tak, aby uwzględniając ograniczenia wynikające z sztywności dużej ich części, zwiększyć udział tych kategorii wydatkowych, które wspierają realizację określonych celów. 
Celem artykułu jest analiza porównawcza zmienności struktury wydatków publicznych, opartej na klasyfikacji COFOG (Classification of the Functions of Government), w krajach Europy Środkowo-Wschodniej w latach 1995-2017. Główne pytania badawcze, na które poszukiwano odpowiedzi to: (1) które kraje aktywnie kształtowały strukturę wydatków publicznych, przesuwając posiadane środki w celu realizacji przyjętych zadań ekonomiczno-społecznych? (2) w których latach struktura wydatków publicznych charakteryzowała się największą zmiennością? (3) które kategorie wydatków publicznych wykazywały największą zmienność? W części empirycznej poddano weryfikacji następującą hipotezę badawczą: najsilniejsze zmiany struktury wydatków publicznych następują w okresach osłabienia gospodarczego, w celu pobudzenia wzrostu i dotyczą szczególnie tych kategorii wydatkowych, które mają bezpośredni wpływ na gospodarkę (wydatki na sprawy gospodarcze, grupa GF04 w klasyfikacji COFOG).

\section{Podstawy teoretyczne}

Mechanizm oddziaływania państwa na wzrost gospodarczy poprzez interwencje fiskalne jest jednym z najważniejszych zagadnień badawczych w obszarze finansów publicznych. Ostatni kryzys finansowy i jego negatywny wpływ na sytuację fiskalną wielu państw był powodem silnej intensyfikacji badań, zarówno w warstwie teoretycznej jak i empirycznej ${ }^{1}$. Analizując skuteczność i efektywność narzędzi fiskalnych należy odróżnić oddziaływanie krótkookresowe (dostosowawcze) od działania długookresowego (wpływ na długookresową ścieżkę wzrostu). Teorie makroekonomiczne wciąż nie są zgodne co do możliwości trwałego zwiększenia długoterminowej stopy wzrostu produkcji. Jednakże wydatki państwa mogą zintensyfikować postęp technologiczny i wzrost produktywności wynikający z inwestycji prywatnych i jest to główny argument uzasadniający interwencje. Potrzeba interwencji państwa jest też związana z obecnością efektów zewnętrznych, które powodują, że stopa wzrostu gospodarki rynkowej jest niższa od optimum społecznego. Zadaniem państwa jest zatem $\mathrm{z}$ jednej strony intensyfikacja tworzenia nowej wiedzy (w sektorze publicznym, w sektorze prywatnym oraz na styku obydwu sektorów), z drugiej zaś usprawnienie rozprzestrzeniania się wiedzy zakumulowanej w przeszłości. Innym argumentem dla interwencji państwa są istniejące niesprawności rynku, takie jak niepełna informacja czy niedoskonałości na rynkach finansowych.

$\mathrm{Z}$ kolei w modelach krótkookresowego wzrostu przedmiotem analizy jest mechanizm dostosowawczy, pozwalający powrócić gospodarce wytrąconej z równowagi na ścieżkę wzrostu. Okres dostosowawczy trwa zwykle kilka lat, a w przywracaniu równowagi ważną rolę może odgrywać aktywnie prowadzona przez państwo antycykliczna polityka stabilizacyjna. Mechanizmem służącym do oceny wpływu wydatków publicznych na krótkookresową aktywność gospodarczą jest mnożnik wydatków fiskalnych, który odgrywa zasadniczą rolę w teorii efektywnego popytu, opartej na założeniu, że w wyniku niedoskonałości rynku gospodarka rynkowa jest systemem inherentnie niestabilnym, a stała interwencja fiskalna państwa jest potrzebna

\footnotetext{
${ }^{1}$ V.A. Ramey: Ten Years After the Financial Crisis, The Journal of Economic Perspectives, Vol. 33, No. 2, 2019, ss. 89-114.
} 
w celu wyrównywania istniejących dysproporcji ${ }^{2}$. Wysokość mnożnika, jego stabilność w czasie, wrażliwość na czynniki zewnętrzne i zróżnicowanie pomiędzy różnymi krajami są przedmiotem licznych badań empirycznych. Wykazano, że skuteczność polityki fiskalnej jest silnie uzależniona od cyklu koniunkturalnego, a mnożnik wydatków publicznych przyjmuje znacznie wyższe wartości w okresie recesji ${ }^{3}$. Innymi czynnikami ekonomicznymi wpływającymi na wysokość mnożnika wydatków są m.in. zakres stosowania automatycznych stabilizatorów, otwartość gospodarki, polityka kursu walutowego, poziom zadłużenia, sprawność rynków finansowych, polityka monetarna, a także wielkość i poziom rozwoju kraju ${ }^{4}$. V. Ramey, zestawiając wyniki badań w tym obszarze, wskazała zakres wartości pomiędzy 0,8 a 1,5 jako najbardziej prawdopodobny szacunek mnożnika ${ }^{5}$, jednak M.Bernardini, S. De Schryder i G. Peersman wykazali jego dużą zmienność, zarówno w przekroju czasowym jak i regionalnym ${ }^{6}$.

Aby skutecznie oddziaływać na gospodarkę poprzez wydatki publiczne, należy oprócz poziomu równocześnie uwzględnić ich strukturę, wydajność i efektywność, a także strukturę podatków i ograniczenia budżetowe, gdyż jak pokazują badania empiryczne, czynniki te są ze sobą wzajemnie powiązane i pominięcie któregoś z nich może osłabić lub zniekształcić efekt finalny ${ }^{7}$. Wpływ wielkości sektora finansów publicznych, mierzonego wartością wydatków publicznych w relacji do PKB, na wzrost gospodarczy, rynek pracy czy inwestycje prywatne ma charakter nieliniowy i niekorzystne dla gospodarki może być zarówno obniżanie wydatków, jak i ich zwiększanie, w zależności od ich aktualnego poziomu. Badania empiryczne dla wybranych krajów UE wskazują na zbyt wysoki poziom wydatków i przekroczenie punktu krytycznego ${ }^{8}, \mathrm{z}$ drugiej strony, niedostateczne wydatki publiczne mogą być niewystarczające dla zapewnienie niezbędnej struktury instytucjonalnej, infrastruktury, porządku i bezpieczeństwa, skutecznie utrudniając rozwój gospodarczy. M. Groneck, w kontekście złotej reguły finansów publicznych, zwraca jednak uwagę na konieczność szerszego spojrzenia na sposób oddziaływania wydatków publicznych, gdyż przy określonej ich kompozycji, nieskuteczności oddziaływania państwa na wzrost gospodarczy może towarzyszyć pozytywny wpływ na szeroko pojęty dobrobyt ${ }^{9}$. Badania

\footnotetext{
${ }^{2}$ K. Łaski, J. Osiatyński i J. Zięba: Mnożnik wydatków państwowych i szacunki jego wielkości dla Polski, NBP Materiały i Studia nr 246, Warszawa 2010, s. 7.

${ }^{3}$ A.Auerbach i Y. Gorodnichenko: Fiscal Multipliers in Recession and Expansion [w:] Fiscal Policy after the Financial Crisis, red. A. Alesina i F. Giavazzi, The University of Chicago Press, Chicago and London 2012, ss. 63-98.

${ }^{4}$ A. Mineshima, M. Poplawski-Ribeiro i A. Weber: Size of fiscal multipliers [w:] Post-crisis fiscal policy, red. C.Cottarelli, P.Gerson i A.Senhadji, The MIT Press, Cambridge 2014, s. 316.

${ }^{5}$ V.A. Ramey: Can Government Purchases Stimulate the Economy, Journal of Economic Literature, 49(3), 2011, ss. 673-685.

${ }^{6}$ M. Bernardini, S. De Schryder i G. Peersman: Heterogeneous Governmen Spending Multipliers in the Era Surrounding the Great Recession, CESifo Working Papers, Munich 2017, s. 4.

${ }^{7}$ M.in. S. Owsiak: Finanse publiczne. Współczesne ujęcie, WN PWN, Warszawa 2017, ss. 311-313, N. Gemmell, R. Kneller i I. Sanz: Does the Composition of Government Expenditure Matter for Long-Run GDP Level?, Oxford Bulletin of Economics and Statistics, 78(4), 2016, ss..522-547, V.A. Ramey: Ten Years After the Financial Crisis, The Journal of Economic Perspectives, Vol. 33, No. 2, 2019, ss. 89-114.

${ }^{8}$ A. Afonso i D. Furceri D: Government Size, Composition, Volatility and Economic Growth, ECB Working Paper no 849, Frankfurt 2008, s. 23.

${ }^{9} \mathrm{M}$. Groneck: The golden rule of public finance and the composition of government expenditures: a growth and welfare analysis, Journal of Economic Policy Reform, vol.14, no. 4, 2011, ss. 273-294.
} 
empiryczne nad polską gospodarką potwierdziły pozytywny wpływ wysokości wydatków publicznych na koniunkturę gospodarcza, wskazując na możliwość aktywnego ich wykorzystywania w celu realizacji polityki prowzrostowej państwa ${ }^{10}$.

Wyznaczenie optymalnej wysokości wydatków publicznych nie jest jednak możliwe bez uwzględnienia ich struktury. Już wczesne modele wzrostu wprowadzały podział na wydatki konsumpcyjne i wydatki inwestycyjne, wykazując że zwiększanie tych drugich daje istotne efekty prowzrostowe, czego nie można zaobserwować w przypadku wydatków konsumpcyjnych. Aktywne kształtowanie struktury wydatków publicznych w celu zwiększenia ich oddziaływania na wzrost gospodarczy jest jednak mocno ograniczone, gdyż wydatki socjalno-administracyjne w dużej części mają charakter wydatków sztywnych ${ }^{11}$, a decyzje alokacyjne charakteryzują się zróżnicowanym horyzontem czasowym ${ }^{12}$.

Wprowadzenie w międzynarodowych statystykach jednolitych standardów klasyfikacji wydatków wg kryterium funkcji (COFOG) spowodowało, że coraz częściej w badaniach empirycznych autorzy analizując wpływ struktury, nawiązują właśnie do struktury funkcjonalnej. Analiza porównawcza wysokości i struktury funkcjonalnej wydatków publicznych w krajach UE, pokazuje istotne zróżnicowanie pomiędzy krajami członkowskimi, a niewielki efekt konwergencji dotyczy wielkości wydatków, ale nie ich struktury $^{13}$, co może świadczyć o konieczności indywidualnego dostosowania prowadzonej polityki fiskalnej do wielkości, zamożności i tempa wzrostu poszczególnych krajów oraz koordynacji z innymi instrumentami oddziaływania na gospodarkę. Przedmiotem analizy w dalszej części artykułu będą wydatki publiczne w krajach Europy Środkowo-Wschodniej, a zatem w grupie znacznie bardziej homogenicznej, ale mimo to także wykazującej istotne zróżnicowanie w wysokości $\mathrm{i}$ kompozycji wydatków publicznych ${ }^{14}$.

\section{Material i metodyka badań}

W badaniach wykorzystano dane dotyczące wysokości wydatków publicznych i ich struktury funkcjonalnej $\mathrm{wg}$ klasyfikacji COFOG $^{15}$, dostępne $\mathrm{w}$ bazie danych EUROSTAT. Na potrzeby prowadzonych analiz dane zostały urealnione z wykorzystaniem deflatora PKB i wyliczone w cenach stałych 2010 r. Zakres czasowy badania, który wyznaczała dostępność danych, objął okres 1995-2017. Okres badawczy, ze względu na dużą zmienność warunków makroekonomicznych, podzielono na sześć

\footnotetext{
${ }^{10}$ M. Lubieniecka: Budżet państwa w obliczu wahań koniunktury gospodarczej na przykładzie gospodarki polskiej, Nierówności społeczne a wzrost gospodarczy, nr 30, 2013, ss. 245-260.

${ }^{11}$ T.M. Budzyński: Analiza struktury wydatków budżetu państwa w Polsce w ujęciu zadaniowym, Acta Universitatis Lodziensis Folia Oeconomica, 1(299), 2014, ss. 9-18.

${ }^{12}$ M. Postuła: Dylematy dotyczące polityki fiskalnej w latach 1995-2012 na przykładzie transformujących się krajów Europy Środkowej, Zeszyty Naukowe UEK, nr 8(932), Kraków 2014, s.111-124.

${ }^{13}$ J. Ferreiro, T. Garcia-Del-Valle i C. Gomez: An Analysis of the Convergence of Public Expenditure in the European Union Countries, American Journal of Economics and Sociology, vol.72, no 4, 2013, ss. 799-825.

${ }^{14}$ J. Sawulski: Finanse publiczne w Polsce - diagnoza na tle innych krajów, IBS Policy Paper, 04/2016, ss. 14-20 .

${ }^{15}$ W klasyfikacji COFOG wyróżnia się dziesięć podstawowych kategorii funkcjonalnych: działalność ogólnopaństwowa (GF01), obrona narodowa (GF02), porządek publiczny i bezpieczeństwo (GF03), sprawy gospodarcze (GF04), ochrona środowiska (GF05), gospodarka mieszkaniowa i komunalna (GF06), ochrona zdrowia (GF07), wypoczynek, kultura i religia (GF08), edukacja (GF09) i opieka społeczna (GF10).
} 
podokresów: P1 - 5-letni okres obejmujący lata 90-te XX w. (1995-2000), P2 - 3 letni okres poprzedzający rozszerzenie Unii Europejskiej (2001-2003), P3 - 4-letni okres do wybuchu światowego kryzysu finansowego (2004-2007), P4 - 3-letni okres światowego kryzysu finansowego (2008-2010), P5 - 3-letni okres pokryzysowy (2011-2013), P6 - 4letni okres kończący analizę (2014-2017). W badaniach wykorzystano dane dotyczące wszystkich krajów UE. Zakres przestrzenny analizy obejmował kraje Europy ŚrodkowoWschodniej $^{16}$ (UE-11), natomiast pozostałe kraje UE stanowily to do oceny zaobserwowanych zależności i trendów.

Ponieważ głównym przedmiotem badania była zmienność wydatków publicznych, zdefiniowano dwie jej miary: wskaźnik zmienności struktury oraz wskaźnik zmienności grupy. Wskaźnik zmienności struktury wydatków ( $\left.\mathbf{W Z S}_{t}\right)$ kumuluje w roku t odchylenia $\mathrm{w}$ realnych stopach wzrostu poszczególnych grup wydatkowych od stopy wzrostu wydatków ogółem. Wskaźnik ten pokazuje, w jakim stopniu poszczególne grupy wydatków zmieniały się w tempie odbiegającym od tempa wzrostu wydatków ogółem, przy czym nie ma znaczenia, czy odchylenie to miało charakter in plus czy in minus. Przyjmuje on wartości nieujemne, a zerowa wartość wskaźnika wskazuje na brak zmienności procentowej struktury wydatków w stosunku do roku poprzedniego (czyli zmiany procentowe we wszystkich grupach były identyczne). W celu ograniczenia wpływu wartości znacznie odbiegających od średniej, wprowadzono górny limit wysokości współczynnika zmienności struktury na poziomie 1000. Wskaźnik wyliczono w wersji prostej:

$$
\mathrm{WZS}_{\mathrm{t}}=\min \left(\sum_{i=1}^{10}\left(\Delta g_{i t}-\Delta_{t}\right)^{2} / 10,1000\right) \quad \text { dla } \mathrm{t}=1996, \ldots, 2017
$$

gdzie: $\mathrm{g}_{\mathrm{i}}$ - grupa wydatków według klasyfikacji COFOG-I (GF01, .., GF10), $\Delta \mathrm{g}_{\mathrm{it}}-$ zmiana wydatków w grupie i w roku t, w\%, $\Delta_{\mathrm{t}}$ - zmiana ogółu wydatków w roku t, w\%.

oraz ważonej, gdzie jako wagi przyjęto udział poszczególnej grupy w strukturze wydatków publicznych w roku t:

gdzie ug $_{\text {it }} \quad(0,1)$ oraz dla każdego $t \Sigma \mathrm{ug}_{\mathrm{it}}=1$

$$
\mathrm{WWZS}_{\mathrm{t}}=\min \left(\sum_{i=1}^{10} u g_{i t}\left(\Delta g_{i t}-\Delta_{t}\right)^{2}, 1000\right)(2)
$$

Wskaźnik zmienności struktury zagregowany na poziomie kraju pozwala zatem zidentyfikować, które kraje w największym stopniu zmieniały strukturę wydatków publicznych, szukając jej optymalnej postaci, lub aktywnie ją kształtując w odpowiedzi na zmieniającą się sytuację makroekonomiczną. $Z$ drugiej strony, agregacja wskaźnika w wyróżnionych podokresach pozwala ocenić, w których latach nastąiły najsilniejsze przesunięcia w strukturze wydatków publicznych.

W celu ustalenia, które grupy funkcjonalne wydatków publicznych wykazywały największą zmienność $w$ ich strukturze, zbudowano wskaźnik zmienności grupy $\left(\mathbf{W Z g}_{\mathbf{i}}\right)$, który kumuluje $\mathrm{w}$ całym badanym okresie odchylenia zmian $\mathrm{w}$ grupie wydatkowej $\mathrm{g}_{\mathrm{i}} \mathrm{w}$ stosunku do zmian w wydatkach ogółem, co przedstawia wzór (3):

$$
\mathrm{WZg}_{\mathrm{i}}=\min \left(\sum_{t=t_{0}}^{t_{0}+n}\left(\Delta g_{i t}-\Delta_{t}\right)^{2} / \mathrm{n}, 1000\right) \text { dla i }=1, \ldots, 10(3)
$$

gdzie: $\mathrm{t}_{0}$ - pierwszy rok okresu badawczego, $\mathrm{n}$ - liczba lat $\mathrm{w}$ analizowanym okresie.

Wskaźnik ten informuje zatem $\mathrm{w}$ jakim stopniu zmiany $\mathrm{w}$ wysokości poszczególnych kategorii wydatkowych były zgodne ze zmianami ogólnego poziomu

${ }^{16}$ Bułgaria, Chorwacja, Czechy, Estonia, Litwa, Łotwa, Polska, Rumunia, Słowacja, Słowenia i Węgry. 
wydatków. Wskaźnik przyjmuje wartości dodatnie, a większe wartości odzwierciedlają wyższą rozbieżność pomiędzy ścieżką zmian w wysokości danej kategorii a ścieżką zmian w wysokości wydatków ogółem, co może świadczyć o aktywnym wykorzystywaniu jej do wpływania na sytuację ekonomiczno-społeczną. Podobnie jak w przypadku wskaźnika zmienności struktury, wprowadzono ograniczenie jego maksymalnej wartości na poziomie 1000.

\section{Wyniki i dyskusja}

Zmienność struktury wydatków publicznych w krajach UE wykazywała duże zróżnicowanie, jednak w zdecydowanie większym stopniu charakteryzowała kraje UE11 niż kraje UE-15. Krajami UE-15 o najmniej stabilnej strukturze wydatków były Włochy, Irlandia i Grecja, czyli kraje, które w analizowanym okresie szczególnie mocno doświadczyły recesji gospodarczej i nierównowagi budżetowej, co mogło okazać się czynnikiem dyscyplinującym do optymalizacji struktury wydatków. Natomiast krajem, w którym w całym badanym okresie funkcjonalna struktura wydatków publicznych prawie nie uległa zmianie, okazała się Francja.

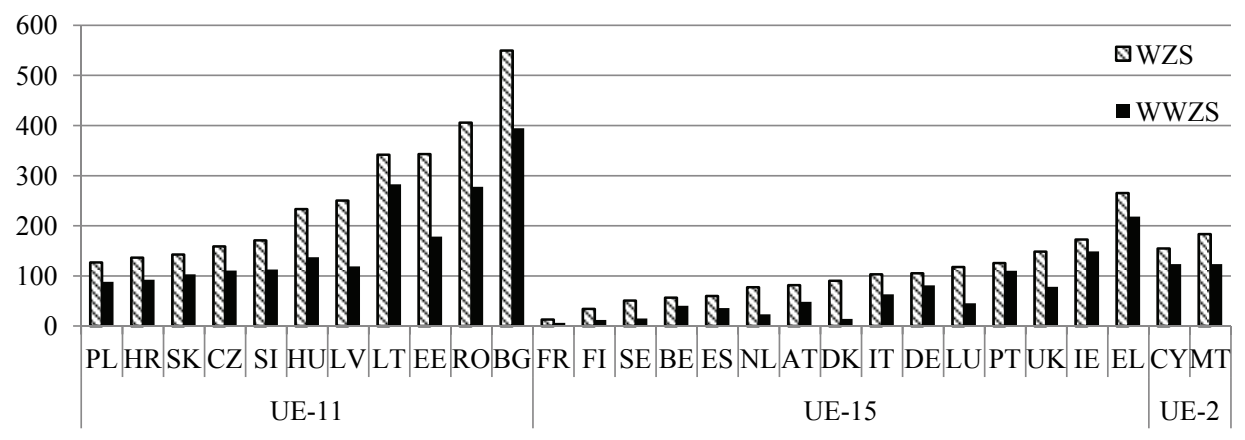

Rysunek 1. Wskaźniki zmienności struktury wydatków publicznych w okresie 1995-2017 Źródło: Opracowanie własne na podstawie danych z Eurostatu.

W krajach UE-11 można zauważyć, że najbardziej zmienną strukturę wydatków mają kraje o najniższym poziomie wydatków w relacji do $\mathrm{PKB}^{17}$, co można tłumaczyć koniecznością bardziej racjonalnego podziału wydatkowych środków. Duża zmienność wydatków w krajach UE-11 jest zgodna z oczekiwaniami, gdyż okres badawczy obejmuje zarówno lata 90-te, w których wciąż wprowadzanych było wiele fundamentalnych zmian wynikających z transformacji rynkowej, jak i późniejsze okresy, zarówno silnego wzrostu gospodarczego jak i recesji.

\footnotetext{
${ }^{17}$ W krajach bałtyckich, Bułgarii i Rumunii średni poziom wydatków publicznych w okresie 1995-2017 nie przekraczał 38\% PKB, podczas gdy w pozostałych krajach UE-11 ukształtował się na poziomie nie mniejszym niż $43 \%$ PKB.
} 

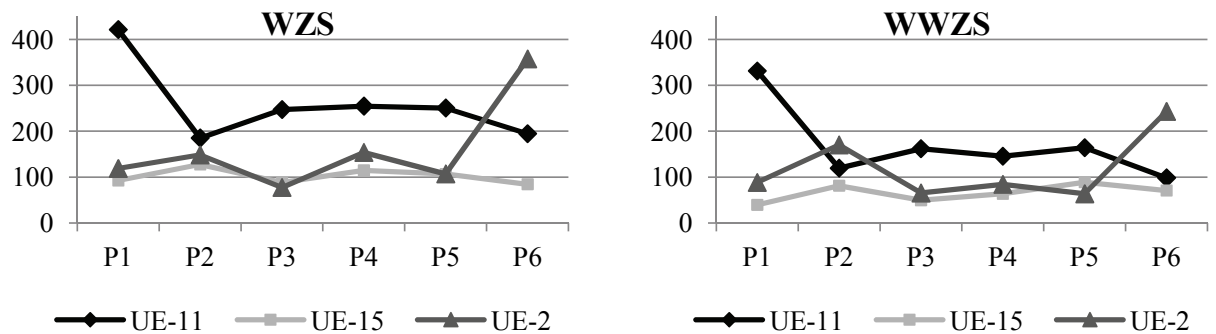

Rysunek 2. Wskaźniki zmienności struktury wydatków publicznych - w wyróżnionych podokresach Źródło: Opracowanie własne na podstawie danych z Eurostatu.

Na rysunku 2 przedstawiono wskaźniki zmienności struktury z rozbiciem na krótsze podokresy, co pozwala potwierdzić, że rzeczywiście lata 90-te były czasem szczególnie silnych zmian w strukturze wydatków publicznych w krajach UE-11, jednak także we wszystkich innych podokresach wskaźnik zmienności struktury ukształtował się znacznie powyżej średniego poziomu dla pozostałych krajów UE. W krajach UE-15 zmiana struktury miała miejsce głównie w okresie poprzedzającym rozszerzenie UE, ale wtedy dotyczyła ona w większym stopniu tych kategorii wydatkowych, które nie miały dużego udziału w strukturze wydatków. Natomiast, co obrazuje wskaźnik ważony, narastającą zmienność wydatków głównych kategorii można zaobserwować w okresie następującym bezpośrednio po kryzysie finansowym (2011-13), a w grupie UE-2 w ostatnim badanym okresie (2014-17).

Tabela 1. Wskaźniki zmienności struktury dla krajów UE-11, w wyróżnionych podokresach

\begin{tabular}{|c|c|c|c|c|c|c|c|c|c|c|c|c|c|c|}
\hline \multirow{2}{*}{ kraj } & \multicolumn{7}{|c|}{ Prosty wskaźnik zmienności struktury, WZS } & \multicolumn{7}{|c|}{ Ważony wskaźnik zmienności struktury, WWZS } \\
\hline & P1 & P2 & P3 & $\mathrm{P} 4$ & P5 & P6 & P1-P6 & P1 & $\mathrm{P} 2$ & P3 & P4 & P5 & P6 & P1-P6 \\
\hline PL & 376,6 & 43,2 & 55,7 & 66,6 & 34,3 & 62,9 & 126,8 & 291,8 & 16,8 & 37,5 & 28,4 & 20,6 & 33,6 & 88,2 \\
\hline HR & $\mathrm{bd}$ & 235,0 & 136,8 & 49,1 & 192,8 & 110,4 & 136,5 & $\mathrm{bd}$ & 164,0 & 140,0 & 38,8 & 105,0 & 40,6 & 92,6 \\
\hline SK & 233,5 & 310,3 & 69,9 & 36,8 & 30,3 & 141,1 & 142,9 & 179,1 & 200,5 & 63,1 & 49,2 & 10,3 & 85,1 & 103,1 \\
\hline $\mathrm{CZ}$ & 206,4 & 223,6 & 137,5 & 123,0 & 168,5 & 91,1 & 158,7 & 199,2 & 157,7 & 93,6 & 31,4 & 127,4 & 29,5 & 110,8 \\
\hline SI & 10,1 & 48,9 & 20,4 & 133,5 & 408,9 & 304,1 & 171,2 & 6,2 & 30,5 & 10,5 & 45,7 & 364,3 & 165,5 & 112,9 \\
\hline LV & 156,6 & 67,3 & 277,2 & 562,7 & 353,5 & 166,6 & 250,4 & 81,0 & 44,1 & 111,0 & 255,8 & 171,4 & 88,3 & 118,9 \\
\hline $\mathrm{HU}$ & 450,0 & 120,8 & 46,4 & 182,8 & 142,1 & 339,9 & 233,3 & 324,3 & 103,0 & 28,9 & 47,3 & 67,1 & 158,1 & 137,4 \\
\hline EE & 66,1 & 132,8 & 600,0 & 690,4 & 662,2 & 89,1 & 342,9 & 42,3 & 57,2 & 290,1 & 415,2 & 333,2 & 34,8 & 178,5 \\
\hline RO & 846,3 & 281,0 & 431,5 & 146,4 & 161,8 & 301,5 & 406,0 & 679,2 & 211,6 & 240,6 & 104,3 & 84,3 & 138,1 & 277,8 \\
\hline LT & 612,2 & 115,1 & 383,1 & 206,9 & 467,7 & 138,5 & 341,7 & 555,7 & 70,2 & 319,1 & 127,1 & 459,1 & 50,3 & 283,0 \\
\hline BG & 926,4 & 476,2 & 560,3 & 603,0 & 133,5 & 395,3 & 549,7 & 692,6 & 274,6 & 448,3 & 457,9 & 63,3 & 260,2 & 394,8 \\
\hline
\end{tabular}

Źródło: Opracowanie własne na podstawie danych z Eurostatu.

Porównując poszczególne kraje UE-11, trudno dostrzec wspólny wzorzec (tab.1). Największa zmienność struktury wydatków publicznych przypadła na pierwszy podokres tylko w pięciu krajach (Polska, Węgry, Rumunia, Bułgaria i Litwa), podczas gdy w Słowenii czy w Estonii dwa pierwsze podokresy należały do najbardziej stabilnych. W Polsce, która na tle innych krajów UE-11 miała najbardziej ustabilizowaną strukturę wydatków, silne zmiany miały miejsce wyłącznie w podokresie $\mathrm{P} 1$, podczas gdy w Czechach czy Bułgarii były w miarę równomiernie rozłożone pomiędzy wszystkie podokresy. W krajach bałtyckich (Estonia, Łotwa) wyraźne zmiany 
struktury miały miejsce w podokresach P3, P4 i P5, w Słowenii głównie w okresach P5 i P6. Wspólną cechą rozkładu zmienności struktury wydatków budżetowych w poszczególnych krajach jest jego uzależnienie od sytuacji makroekonomicznej w Polsce, która uniknęła recesji gospodarczej, stabilność struktury wydatków była największa, w krajach bałtyckich wokresach P3-P5 silnym wahaniom wzrostu gospodarczego towarzyszyły największe przesunięcia pomiędzy różnymi kategoriami wydatków.

W drugim etapie przedmiotem analizy była zmienność poszczególnych kategorii wydatków publicznych. Ich udział w strukturze wydatków ogółem przedstawiono w tabeli 2.

Tabela 2. Struktura wydatków publicznych, średnie dla okresu 1995-2017

\begin{tabular}{|l|r|r|r|r|r|r|r|r|r|r|}
\hline kraje & \multicolumn{1}{|c|}{ GF01 } & \multicolumn{1}{c|}{ GF02 } & \multicolumn{1}{c|}{ GF03 } & \multicolumn{1}{c|}{ GF04 } & \multicolumn{1}{c|}{ GF05 } & GF06 & GF07 & \multicolumn{1}{c|}{ GF08 } & \multicolumn{1}{c|}{ GF09 } & \multicolumn{1}{c|}{ GF10 } \\
\hline UE-15 & 15,5 & 2,8 & 3,3 & 9,9 & 1,6 & 1,5 & 13,7 & 2,3 & 11,0 & 38,2 \\
\hline UE-11 & 13,9 & 3,4 & 5,1 & 13,6 & 1,7 & 2,2 & 12,4 & 3,1 & 12,3 & 32,3 \\
\hline UE-2 & 18,9 & 3,4 & 4,2 & 12,1 & 1,9 & 3,7 & 9,8 & 2,1 & 14,3 & 29,6 \\
\hline
\end{tabular}

Źródło: Eurostat.

Współczynnik zmienności grup WZG wskazuje, które grupy wydatków wykazywały się największą zmiennością (rys.3). Zgodnie z oczekiwaniami, największą stabilność wykazywały te grupy wydatków, których udział w strukturze był największy, takie jak wydatki na opiekę socjalną (GF10), na edukację (GF09), czy na ochronę zdrowia (GF07). W krajach UE-15 największą zmienność wykazały grupa wydatków na sprawy gospodarcze (GF04), posiadająca około 10\% udział w strukturze wydatków oraz wydatki na budownictwo mieszkaniowe i komunalne (GF06; o znikomym i malejącym udziale).

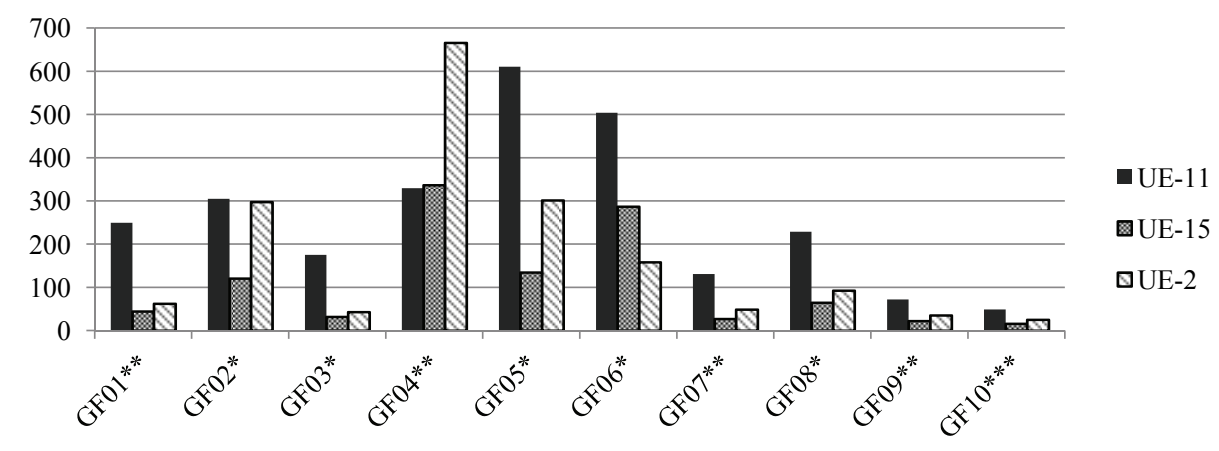

Rysunek 3. Wskaźnik zmienności grup wydatków publicznych, okres 1995-2017

Uwaga: gwiazdkami oznaczono znaczenie określonej kategorii w strukturze wydatków publicznych: *** oznacza wysoki udział, ** średni udział (ok. 10\%), * niski udział, nie przekraczający 5\%.

Źródło: opracowanie własne.

W krajach UE-11 niemal wszystkie kategorie wydatków wykazywały większą zmienność niż w krajach UE-15, z czego największą wydatki na ochronę środowiska 
(GF05), na budownictwo komunalne (GF06), a także na działalność ogólnopaństwową (GF01), obronę narodową (GF02), bezpieczeństwo i porządek publiczny (GF03) oraz kulturę (GF08). Należy jednak podkreślić, że w krajach UE-11 wydatki na sprawy gospodarcze były jedyną kategorią wydatków, którą charakteryzowała mniejsza zmienność niż w pozostałych krajach UE (chociaż równocześnie ich udział w wydatkach ogółem był w krajach UE-11 o niemal 4 p.p. wyższy niż w krajach UE-15). Jest to o tyle istotne, że właśnie ta kategoria wydatków ma najsilniejsze bezpośrednie oddziaływanie prowzrostowe, a zatem ich zmienność może oznaczać aktywne prowadzenie polityki fiskalnej.

Tabela 3. Wskaźnik zmienności grup wydatków publicznych, dla wyróżnionych podokresów

\begin{tabular}{|c|c|c|c|c|c|c|c|c|c|c|c|}
\hline kraje & okres & GF01 & GF02 & GF03 & GF04 & GF05 & GF06 & GF07 & GF08 & GF09 & GF10 \\
\hline \multirow{6}{*}{ UE-11 } & $\mathrm{P} 1$ & 318 & 365 & 296 & 411 & 490 & 506 & 359 & 291 & 157 & 92 \\
\hline & $\mathrm{P} 2$ & 156 & 131 & 119 & 196 & 297 & 396 & 92 & 208 & 119 & 39 \\
\hline & P3 & 206 & 215 & 35 & 93 & 432 & 351 & 97 & 113 & 28 & 36 \\
\hline & P4 & 145 & 258 & 75 & 192 & 488 & 388 & 50 & 139 & 42 & 74 \\
\hline & $\mathrm{P} 5$ & 137 & 198 & 47 & 247 & 490 & 194 & 45 & 135 & 70 & 31 \\
\hline & P6 & 71 & 365 & 48 & 192 & 392 & 381 & 21 & 262 & 21 & 25 \\
\hline \multirow{6}{*}{ UE-15 } & P1 & 43 & 131 & 29 & 133 & 185 & 220 & 18 & 80 & 19 & 11 \\
\hline & $\mathrm{P} 2$ & 39 & 64 & 58 & 221 & 69 & 234 & 26 & 70 & 8 & 4 \\
\hline & P3 & 21 & 33 & 8 & 181 & 136 & 225 & 23 & 46 & 12 & 8 \\
\hline & $\mathrm{P} 4$ & 57 & 205 & 54 & 214 & 142 & 358 & 51 & 74 & 47 & 42 \\
\hline & P5 & 98 & 116 & 27 & 240 & 96 & 119 & 45 & 89 & 50 & 24 \\
\hline & P6 & 26 & 127 & 28 & 175 & 36 & 92 & 14 & 34 & 10 & 14 \\
\hline
\end{tabular}

Źródło: opracowanie własne.

W krajach UE-15 niemal we wszystkich kategoriach wydatków o znaczącym udziale w strukturze wydatków ogółem, ich największa zmienność przypadła na dwa okresy: okres kryzysu finansowego (P4) oraz okres następujący bezpośrednio po nim (P5). Wyjątek stanowiły tu wydatki na sprawy gospodarcze, które $\mathrm{z}$ jednej strony wykazywały największą zmienność wśród wszystkich kategorii, z drugiej zaś, zmienność ta utrzymywała się we wszystkich podokresach (tab.3). Warto jednak zauważyć, że właśnie w okresach P4-P5 w niektórych krajach zaangażowanie funduszy publicznych w celu łagodzenia skutków zaburzeń finansowych spowodowało krótkoterminowy, skokowy wzrost udziału grupy GF04 (do 26\% w Grecji w 2013 r, czy nawet 38,5\% w Irlandii w 2010 r.). W krajach UE-11 największa zmienność w każdej grupie przypadła na okres startowy P1. Dominująca grupa wydatków, związanych z realizacją funkcji opieki socjalnej (GF10), podobnie jak w krajach UE-15 zwiększyła swoją zmienność w okresie kryzysu P4. Wydatki na edukację (GF09), miały największą zmienność głównie przed 2004 rokiem. Kategoria ta odgrywa kluczową rolę jako czynnik prorozwojowy, poprzez kształtowanie kapitału ludzkiego, jednak ze względu na silne opóźnienia czasowe jej oddziaływanie ma charakter długofalowy. Wygaszającą zmienność wykazywały także wydatki na ochronę zdrowia (GF07). Natomiast dwie pozostałe kategorie o średnim udziale w strukturze wydatków, czyli wydatki na sprawy gospodarcze (GF05) oraz wydatki na działalność ogólnopaństwową (GF01) utrzymały silną zmienność w całym badanym okresie. 
W tabeli 4 przedstawiono wskaźniki zmienności poszczególnych kategorii wydatków publicznych dla krajów UE-11. Krajami, w których silna zmienność dotyczyła większości grup wydatkowych, były Bułgaria, Rumunia i, w mniejszym stopniu, Litwa, natomiast w pozostałych krajach zmienność koncentrowała się głównie w kilku wybranych grupach wydatkowych.

Tabela 4. Wskaźnik zmienności grup wydatków publicznych, dla krajów UE-11, w okresie 1995-2017

\begin{tabular}{|l|r|r|r|r|r|r|r|r|r|r|}
\hline Kraje & \multicolumn{1}{c|}{ GF01 } & \multicolumn{1}{l}{ GF02 } & \multicolumn{1}{c|}{ GF03 } & \multicolumn{1}{l}{ GF04 } & \multicolumn{1}{c|}{ GF05 } & GF06 & GF07 & GF08 & GF09 & GF10 \\
\hline BG & 655 & 653 & 387 & 594 & 896 & 1000 & 457 & 760 & 93 & 76 \\
\hline CZ & 159 & 208 & 61 & 208 & 321 & 429 & 54 & 81 & 18 & 48 \\
\hline EE & 83 & 187 & 58 & 49 & 1000 & 1000 & 16 & 60 & 10 & 29 \\
\hline HR & 143 & 45 & 31 & 56 & 160 & 129 & 83 & 295 & 28 & 22 \\
\hline HU & 57 & 315 & 45 & 263 & 668 & 1000 & 20 & 288 & 37 & 13 \\
\hline LT & 1000 & 267 & 93 & 556 & 1000 & 450 & 199 & 88 & 172 & 146 \\
\hline LV & 55 & 348 & 74 & 106 & 1000 & 286 & 109 & 91 & 41 & 69 \\
\hline PL & 46 & 134 & 82 & 487 & 267 & 98 & 104 & 128 & 12 & 17 \\
\hline RO & 365 & 1000 & 1000 & 194 & 1000 & 335 & 143 & 551 & 237 & 40 \\
\hline SI & 79 & 92 & 36 & 1000 & 300 & 284 & 42 & 127 & 31 & 30 \\
\hline SK & 103 & 102 & 60 & 109 & 102 & 529 & 212 & 46 & 116 & 50 \\
\hline
\end{tabular}

Źródło: opracowanie własne.

Dla większości krajów grupami o silnej zmienności były wydatki na ochronę środowiska oraz budownictwo komunalne i mieszkaniowe, ale te grupy wydatków miały niewielki udział w ich ogólnej wartości. Wydatki na kulturę miały dużą zmienność w Chorwacji i na Węgrzech, a na obronę narodową w Estonii, Łotwie, Rumunii i na Węgrzech. Natomiast spośród kategorii o średnim udziale w strukturze, największą zmienność wykazały wydatki na sprawy gospodarcze, szczególnie w Słowenii, Polsce, Czechach, na Litwie i Węgrzech. Warto jednak podkreślić, że czasowy rozkład zmienności wydatków na gospodarkę był w tych krajach istotnie zróżnicowany: podczas gdy w Czechach, Rumunii czy Chorwacji zmiany koncentrowały się głównie w pierwszych podokresach, w Słowenii i na Łotwie miały miejsce głównie w okresie pokryzysowym. W Polsce bardzo silna zmienność tej kategorii wydatków miała miejsce w pierwszym podokresie P1, potem wykazując już względną stabilizację.

\section{Podsumowanie}

Struktura wydatków publicznych jest ważnym instrumentem oddziaływania na gospodarkę, szczególnie w sytuacji ograniczeń budżetowych, kiedy niemożliwy jest wzrost ich wysokości. Miernikiem, który może informować w jakim stopniu jest ona dostosowywana do bieżących wyzwań i długookresowych zadań jest jej zmienność. $\mathrm{W}$ artykule celu zbadania zmienności wydatków publicznych zaproponowano dwa wskaźniki - wskaźnik zmienności struktury (w wersji prostej i ważonej) oraz wskaźnik zmienności grupy. W krajach Europy Środkowo-Wschodniej zmienność struktury wydatków publicznych była znacznie większa niż w krajach UE-15, i to zarówno w okresie przed akcesją do UE jak i później. Największą zmienność struktury wydatków można było zauważyć $\mathrm{w}$ krajach o niskim poziomie wydatków publicznych w relacji 
do PKB, oraz w okresach słabego wzrostu gospodarczego, co wskazywałoby na próby jej optymalizacji przez aktywne kształtowanie zwłaszcza w sytuacji ich ograniczonej wysokości i w celu silniejszego oddziaływania na gospodarkę. Wydatki na sprawy gospodarcze okazały się kategorią wydatków wykazująca najsilniejszą zmienność w krajach UE-15 oraz UE-2, natomiast w krajach UE-11, choć wykazały największą zmienność spośród wydatków o średnim lub dużym udziale w strukturze, były bardziej stabilne niż wydatki na ochronę środowiska lub budownictwa komunalne i mieszkaniowe. W Polsce wydatki na sprawy gospodarcze były aktywnie kształtowane głównie w początkowych latach badanego okresu, potem zaś ich zmienność uległa wygaszeniu. Analiza porównawcza stabilności wydatków publicznych w badanych krajach, dokonana na podstawie wskaźników zmienności, potwierdza postawioną hipotezę badawczą, że najsilniejsze zmiany w strukturze wydatków następują w okresie spowolnienia gospodarczego, a kategorią odgrywająca istotne znaczenie są wydatki na sprawy gospodarcze. Z drugiej jednak strony, w krajach ESW trudno zidentyfikować podobne wzorce zmienności struktury wydatków, co wskazywałoby na silne znaczenie czynników jednostkowych, takich jak przyjęte priorytety $\mathrm{w}$ prowadzonej polityce ekonomiczno-społecznej.

\section{Literatura}

Afonso A., Furceri D.: Government Size, Composition, Volatility and Economic Growth, ECB Working Paper no 849, Frankfurt 2008.

Auerbach A., Gorodnichenko Y.: Fiscal Multipliers in Recession and Expansion [w:] Fiscal Policy after the Financial Crisis, red. A.Alesina i F.Giavazzi, The University of Chicago Press, Chicago and London 2013.

Bernardini M., De Schryder S., Peersman G.: Heterogeneous Governmen Spending Multipliers in the Era Surrounding the Great Recession, CESifo Working Papers, Munich 2017.

Budzyński T.M.: Analiza struktury wydatków budżetu państwa w Polsce w ujęciu zadaniowym, Acta Universitatis Lodziensis Folia Oeconomica, 1(299), 2014.

Eurostat data code: [gov_10a_exp]), dostęp: http://appsso.eurostat.ec.europa.eu/nui/show.do?dataset=gov_10a_exp\&lang=en..

Ferreiro J., Garcia-Del-Valle T., Gomez C.: An Analysis of the Convergence of Public Expenditure in the European Union Countries, American Journal of Economics and Sociology, vol.72, no.4, 2013.

Gemmell N., Kneller R., Sanz I.: Does the Composition of Government Expenditure Matter for Long-Run GDP Level?, Oxford Bulletin of Economics and Statistics, 78(4), 2016.

Groneck M.: The golden rule of public finance and the composition of government expenditures: a growth and welfare analysis, Journal of Economic Policy Reform, vol.14, no. 4, 2011.

Lubieniecka M.: Budżet państwa w obliczu wahań koniunktury gospodarczej na przykładzie gospodarki polskiej, Nierówności społeczne a wzrost gospodarczy, nr 30, 2013.

Łaski K., Osiatyński J., Zięba J.: Mnożnik wydatków państwowych i szacunki jego wielkości dla Polski, Materiały i Studia nr 246, NBP, Warszawa 2010.

Mineshima A., Poplawski-Ribeiro M., Weber A.: Size of fiscal multipliers [w:] Post-crisis fiscal policy, red. C.Cottarelli, P.Gerson i A.Senhadji, The MIT Press, Cambridge 2014.

Owsiak S.: Finanse publiczne. Współczesne ujęcie, WN PWN, Warszawa, 2017.

Postuła M.: Dylematy dotyczące polityki fiskalnej w latach 1995-2012 na przykładzie transformujących się krajów Europy Środkowej, Zeszyty Naukowe UEK, nr 8(932), 2014. 
Ramey V.A.: Can Government Purchases Stimulate the Economy, Journal of Economic Literature, 49(3), 2011.

Ramey V.A.: Ten Years After the Financial Crisis, The Journal of Economic Perspectives, vol. 33, no. 2, 2019.

Sawulski J.: Finanse publiczne w Polsce - diagnoza na tle innych krajów, IBS Policy Paper, $04 / 2016$

\begin{abstract}
The article presents a comparative analysis of the variability of public expenditure structures in Central and East European countries in the period 1995-2017. To measure the volatility, two indicators were proposed: one reflecting the variability of the expenditure structures, and the other reflecting the variability of each expenditure category. The above indicators allowed verification of the research hypothesis that the strongest changes in the structure of public spending occur in periods of economic recession and concern, in particular, expenditure categories having a direct impact on the economy. In the countries of Central and Eastern Europe, the largest variability in expenditure structure was demonstrated by countries with the lowest level of public expenditure in relation to GDP, which confirms that a small budget enforces its rationalization. In turn, the highest stability of the expenditure structure in the analyzed period was found in Poland, which may be associated with its smooth growth and subsequent avoidance of the economic recession. The group of expenditures that was most actively changed, both in the old and new EU member states, were expenditures on economic affairs.
\end{abstract}

Key words: public spending, COFOG, public expenditure structure, Central and Eastern Europe. JEL Codes: H50, O23.

Informacje o autorze:

dr Katarzyna Mikolajczyk

Uniwersytet Ekonomiczny w Krakowie

ul.Rakowicka 27, Kraków, Polska

e-mail:mikolajk@uek.krakow.pl

ORCID: 0000-0002-9120-0897 